J. Amer. Soc. Hort. SCI. 127(4):535-539. 2002.

\title{
Cloning of a Wound Inducible Lycopersicon esculentum Cytochrome P450 Gene and Lack of Regeneration of Transgenic Plants with Sense or Antisense Constructs
}

\author{
Grzegorz Bartoszewski \\ Department of Plant Genetics, Breeding and Biotechnology, Faculty of Horticulture and Landscape \\ Architecture, Warsaw Agricultural University, 02-787 Warsaw, Poland \\ Cesar V. Mujer \\ Molecular Plant Pathology Laboratory, U.S. Department of Agriculture, Agricultural Research Service, \\ 10300 Baltimore Avenue, Beltsville, MD 20705
}

Katarzyna Niemirowicz-Szczytt

Department of Plant Genetics, Breeding and Biotechnology, Faculty of Horticulture and Landscape Architecture, Warsaw Agricultural University, 02-787 Warsaw, Poland

\author{
Ann C. Smigocki ${ }^{1}$ \\ Molecular Plant Pathology Laboratory, U.S. Department of Agriculture, Agricultural Research Service, \\ 10300 Baltimore Avenue, Beltsville, MD 20705
}

\begin{abstract}
ADDITIONAL INDEX WORDS. tomato, biotechnology, zeatin, cytokinin
Abstract. A Lycopersicon esculentum Mill. (tomato) cDNA clone with high similarity to a Nicotiana plumbaginifolia Viv. (tobacco) cytochrome $\mathbf{P 4 5 0}$ gene was isolated using 5 ' and 3 ' rapid amplification of cDNA ends (RACE). The isolated cDNA (GenBank Accession No. AF249329) has an open reading frame of 1494 base pairs (bp) and encodes a protein of 498 amino acids with $75 \%$ identity to the $N$. plumbaginifolia cytochrome P450 (CYP72A2) and $45 \%$ to a Catharanthus roseus G. Don (Madagaskar periwinkle) CYP72A1 protein sequence. By Southern-blot analysis, one or two highly homologous genes were detected in the $L$. esculentum genome. Expression of the cloned $\mathbf{P 4 5 0}$ gene was regulated by circadian rhythm and enhanced by wounding. Leaf transcripts were detected in the light but not dark. Highest transcript levels were observed 3 hours after mechanical wounding. No increase in expression was seen in response to applications of zeatin as with the $N$. plumbaginifolia gene. Of the tissues analyzed, shoot tips and young leaves and fruit had the highest detectable transcript levels. Attempts to transform more than 1400 cotyledon explants of $L$. esculentum with sense or antisense CYP72A2 gene constructs produced no transgenic plants.
\end{abstract}

Plant cytochrome P450s form a large family of enzymatic proteins that are involved in the synthesis of a variety of secondary metabolites. They are heme-containing monooxygenases inserting one atom of oxygen into molecules to make them more reactive and hydrosoluble (Nebert and Gonzalez, 1987). They participate in the synthesis of hormones, sterols, fatty acids, plant allelochemicals (insect toxins, repellants, or attractants) and xenobiotics (pesticides and herbicides) (O'Keefe et al., 1994; Schuler 1996; Shiota et al., 1994; Werck-Reichhart et al., 2000). The plant P450 genes have been divided into 85 subfamilies called CYP (Nelson, 1999).

We cloned a P450 cDNA (Gen Bank Accession No. U35226) designated as CYP72A2 from Nicotiana plumbaginifolia (tobacco) plants that were transformed with an isopentenyl transferase (ipt) gene that regulates synthesis of cytokinins (Mujer and Smigocki, 2001). Its deduced amino acid sequence had $45 \%$ identity to a Catharanthus roseus (Madagaskar periwinkle) CYP72Al gene (GenBank Accession No. L10081) that codes for secologanin synthase and was cloned from a cell culture line selected for high indole alkaloid biosynthesis (Irmler et al., 2000;

Received for publication 27 Aug. 2001. Accepted for publication 2 Apr. 2002. This work was supported by MR/USDA-97-295 joint project funded by the U.S.Poland Maria Sklodowska-Curie Joint Fund II.

${ }^{1}$ Corresponding author; e-mail smigocki@asrr.arsusda.gov.
Vetter et al., 1992). Many monoterpene indole alkaloids have been shown to be insect deterrents and toxins as well as potent anticancer drugs. Mechanical wounding, feeding larvae, and cytokinins induced a higher level of expression of the $N$. plumbaginifolia CYP72A2 gene (Mujer and Smigocki, 2001). The response to wounding was shown to be systemic and occurred more rapidly in response to insect attack, suggesting a possible role for this gene in plant defense responses.

Based on the N. plumbaginifolia CYP72A2 cDNA sequence, we cloned the Lycopersicon esculentum (tomato) homologue. Molecular characterization of the L. esculentum gene that shares high sequence homology with the $N$. plumbaginifolia gene is presented. Circadian rhythm and wounding but not cytokinin were shown to regulate expression of the L. esculentum gene. In addition, since transformation experiments with the $C Y P 72 A 2$ gene produced no L. esculentum transformants, we suggest that gene expression may need to be stringently regulated in transformed cells.

\section{Materials and Methods}

Plant material and culture conditions. 'Rutgers' tomato was used in all cloning and expression studies. For tomato transformation experiments, 'Rutgers', 'Beta' and line nor (carrying a nonripening mutation) were used. Lycopersicon esculen- 
tum plants were grown in the greenhouse in Bacto Lite potting soil (Michigan Peat Co., Houston) and fertilized twice a month with Peters $20 \mathrm{~N}-8.8 \mathrm{P}-16.6 \mathrm{~K}$ water-soluble fertilizer (United Industries Corp., St. Louis). Day/night greenhouse temperatures were $26 \pm 4 / 19 \pm 1{ }^{\circ} \mathrm{C}$ with an approximate photoperiod of $16 \mathrm{~h}$. For wounding experiments, plants were grown in a growth chamber with days/nights of $25 / 20{ }^{\circ} \mathrm{C}$ with a 16 -h photoperiod of $270 \mu \mathrm{mol} \cdot \mathrm{m}^{-2} \cdot \mathrm{s}^{-1}$ provided by cool-white fluorescent lamps (Environmental Growth Chambers, Chagrin Falls, Ohio).

Wounding ExPERIMENTs. Two fully expanded leaves of the tomato plants (three- to four-leaf stage) grown in a growth chamber were wounded. Control plants were not wounded. Three wounded plants as well as three nonwounded plants were used for every time point. Each leaflet was cut six times with scissors. Three $1.5 \mathrm{~cm}$ cuts were made on each side of the leaflet (without cutting through the midvein) at $0900 \mathrm{HR}$ and samples were collected at $0,3,6,12,24,36$, or $48 \mathrm{~h}$ after wounding. Collected tissue was frozen in liquid nitrogen for analysis.

ZEATIN TREATMENT. Zeatin was applied to greenhouse-grown plants of L. esculentum at the four- to five-leaf stage. Zeatin was dissolved in $0.5 \mathrm{~N} \mathrm{NaOH}$ and then diluted to $5 \times 10^{-5}$ and $5 \times 10^{-}$ ${ }^{6} \mathrm{M}$ in distilled water. Distilled water was used as a control and the $\mathrm{pH}$ of all solutions was adjusted to 6.8. Plants were sprayed so all leaves were moist at $0900 \mathrm{HR}$ in triplicate and fully expanded leaves were collected right after and during the day at 2 and $6 \mathrm{~h}$ after spraying.

ZEATIN UPTAKE. Shoots with one expanded leaf were cut at $2100 \mathrm{HR}$ (in the dark) from greenhouse grown plants of L.esculentum, at the four- to five-leaf stage and transferred into $50 \mathrm{~mL}$ half-strength MS salts (Murashige and Skoog, 1962) with varying zeatin concentrations of $5 \times 10^{-5}, 5 \times 10^{-6}$, or $5 \times 10^{-7} \mathrm{M}$. After $36 \mathrm{~h}$ in the dark, leaves were collected and frozen in liquid nitrogen.

Tissue COLlection for P450 expression anAlysis. Tissue samples were collected from different organs of greenhouse grown plants with two to three flower clusters. Samples were collected at $0900 \mathrm{HR}$ from roots, stems (3- to 5-cm sections of main stems that were above the first flower clusters), expanded leaves, young leaves ( 1 to $2 \mathrm{~cm}$ long), mature flowers, young fruit (diameter $1 \mathrm{~cm}$ ), green fruit (diameter 5 to $6 \mathrm{~cm}$ ), and shoot tips ( $\approx 1 \mathrm{~cm}$ long).

Polymerase Chain Reaction (PCR). PCR was carried out in a reaction mixture consisting of $10 \mathrm{~mm}$ Tris- $\mathrm{HCl}(\mathrm{pH} \mathrm{8.3)}$, primers (1 $\mu \mathrm{M}$ each), $200 \mu \mathrm{M}$ of each dNTP, $1.5 \mathrm{mM} \mathrm{MgCl}_{2}$, $0.001 \% \mathrm{w} / \mathrm{v}$ gelatin and 20 units/mL Amplitaq DNA polymerase (Perkin Elmer/Cetus, Norwalk, Conn.) as per manufacturer's protocol. L. esculentum genomic DNA (50 to $100 \mathrm{ng}$ ) was used as template.

A reverse transcription system kit (Promega, Madison, Wis.) was used for reverse transcription PCR (RT-PCR). cDNA was synthesized from $1.5 \mu \mathrm{g}$ of total RNA extracted $6 \mathrm{~h}$ after mechanical wounding of the leaves. The cDNA was then PCR amplified as above using 100 to $200 \mathrm{ng}$ of total cDNA as template. Primers specific for the $N$. plumbaginifolia cDNA sequence, reverse primer 5'-AAG TTT GTG GAC GAT TAT CTG AGC ACC ATA-3' corresponding to position 1623 to 1652 and forward primer 5'-TAT ACA ATA TGG TGG TGG CCA AAG ATG ATA-3' corresponding to position 198 to 227 (Mujer and Smigocki, 2001) produced a DNA band of expected size which was sequenced.

The 5' AND 3' RAPID AMPLIFICATION OF CDNA ENDS (RACE). Total RNA was isolated from leaves $6 \mathrm{~h}$ after wounding (1500 HR) and treated with DNAseI. Smart RACE (Clontech, Palo Alto,
Calif.) was used to generate 5' and 3'-RACE Ready cDNA according to manufacturer's protocol using Superscript 2 reverse transcriptase (Life Technologies, Rockville, Md.). Based on results of the RT-PCR, the following primers were paired with the SMART primers in the kit: reverse primer for 5'-RACE was 5'AAG TTT GTG GAC GAT TAT CTG AGC ACC ATA-3' and forward primer for 3'-RACE was 5'-TAT ACA ATA TGG TGG TGG CCA AAG ATG ATA-3'. From the sequenced RACE products, the following primers were designed to overlap the whole cDNA and provide SalI and HindIII restriction enzyme sites to facilitate cloning: SalI (underlined) Forward 5'-CGC GTC GAC ACG CGG GGA GTC CAA TAA ACC TTT GCT CTG3' and HindIII (underlined) Reverse 5'-GGC AAG CTT TTA ATA GTG CTA ATG AGA GTT TGT CAC ACA-3'. The full length cDNA was amplified from the 5'-RACE Ready cDNA using Advantage DNA polymerase (Clontech) and directionally cloned into pGEM-4Z plasmid (Promega).

HYBRIDIZATION EXPERIMENTS. DNA was isolated from young leaves according to Dellaporta et al. (1984). For Southern blots, $10 \mu \mathrm{g}$ of genomic DNA was digested with restriction enzymes (Life Technologies). After electrophoresis, separated DNA was transferred to Zeta-Probe membrane (Bio-Rad, Hercules, Calif.). RNA was isolated from L. esculentum tissues (Mujer and Smigocki, 2001) and $20 \mu \mathrm{g}$ was electrophoresed on a $1.2 \%$ formaldehydeagarose gel for transfer to Zeta-Probe membranes. Membranes were hybridized overnight at $65{ }^{\circ} \mathrm{C}$ with a ${ }^{32} \mathrm{P}$-labeled probe (Random Primed DNA Labeling Kit, Boehringer Mannheim, Indianapolis) in $1 \mathrm{~mm}$ ethylenediaminetetraacetic acid (EDTA), $0.5 \mathrm{M} \mathrm{NaHPO}_{4}$, and 7\% sodium dodecyl sulfite (SDS) as described by Church and Gilbert (1984). A $0.4 \mathrm{~kb}$ fragment of the $5^{\prime}$ end of the cDNA corresponding to position -84 to 293 was used as a probe. After hybridization, membranes were washed at $65^{\circ} \mathrm{C}$ for $20 \mathrm{~min}$ in $1 \mathrm{~mm}$ EDTA, $40 \mathrm{~mm} \mathrm{NaHPO}_{4}$ and 5\% SDS two times, and in 1 mMEDTA, $40 \mathrm{~mm} \mathrm{NaHPO}_{4}$ and $1 \% \mathrm{SDS}$ two times (high stringency) according to Church and Gilbert (1984). Hybrids were analyzed with a blot analyzer (Betascope 603; Betagen Corp., Waltham, Mass.) and exposed to X-OMAT AR film (Eastman Kodak Co., Rochester, N.Y.). Experiments were conducted two times.

DNA SEQUENCING AND DATA ANALYSIS. Automated sequencing was performed by the Biotechnology Facility, Center for Agricultural Biotechnology, University of Maryland, College Park. The nucleotide and the deduced amino acid sequence analyses were performed using Wisconsin Package Version 10.0, Genetics Computer Group (GCG), Madison, Wis. The CLUSTALw program (Thompson et al., 1994) was used to align the amino acid sequences. GenBank was searched for expressed sequence tags (ESTs) using the Blast program at the National Center for Biotechnology Information (NCBI) (Altschul et al., 1997).

BINARY PLASMID CONSTRUCTION. Full length CYP72A2 cDNA was directionally cloned behind the $35 \mathrm{~S}$ CaMV promoter in the sense (pFLS) or antisense (pFLAS) orientation, respectively, in the pCAMBIA1380-35S binary plasmid that carries the HPTII selectable marker gene for selection of transformed plant cells (CAMBIA, Canberra, Australia). Plasmid pTRAS was obtained by cloning the 5' end of the cDNA fragment (corresponding to bp 198 to 878 ) into the same pCAMBIA1380-35S plasmid in the antisense orientation. Plasmid pPin2FLS carries the full length CYP72A2 gene fused to a wound inducible pin2 promoter (Mujer and Smigocki, 2001). All chimeric genes were sequenced and each plasmid was introduced into Agrobacterium tumefaciens strain LBA4404 (Life Technologies) by electroporation. 
Lycopersicon esculentum TRANSFORMATION. Experiments were performed according to McCormick et al. (1986). Cotyledon explants from aseptically grown seedlings of three tomato genotypes, 'Rutgers', 'Beta' and line nor, were inoculated with $A$. tumefaciens strains (Bartoszewski et al., 1996) carrying the P450 gene constructs or the control 35S-GUS construct (Jefferson et al., 1987).

\section{Results and Discussion}

Sequence analysis of the Cytochrome P450 gene. The cloned L. esculentum P450 cDNA is 1734 bp long and contains a full length, open reading frame of $1494 \mathrm{bp}$. The deduced amino acid sequence of 498 amino acids shared $75 \%, 45 \%$, and $44 \%$ identity with the $N$. plumbaginifolia $C Y P 72 A 2$ (U35226), $C$. roseus CYP72A1 (L10081), and Arabidopsis thaliana(L.) Heynh. (AB023038) cytochrome P450 clones, respectively. The molecular weight and isoelectric point of the predicted protein were determined to be $57.3 \mathrm{ku}(\mathrm{u}=$ unified atomic mass unit) and 9.11 , respectively, and were similar to the $N$. plumbaginifolia $C Y P 72 \mathrm{~A} 2$ protein (Mujer and Smigocki, 2001). A PCR-amplified genomic clone that was obtained using the same primers had three small introns of 79, 78, and $85 \mathrm{bp}$ at nucleotides 486, 731, and 1078, respectively. Southern-blot results suggest that there are either one or two genes that are highly homologous and that they are clustered in the L. esculentum genome (Fig. 1). A probe specific for the 5' end of the P450 cDNA hybridized to one (EcoRV, KpnI, PstI, and SstI) or two (BlgII, DraI, HindIII, and ScaI) bands of the L. esculentum DNA that was restricted with enzymes with no corresponding sites in the probe or the genomic clone. The less intense bands observed with the BamHI and EcoRI enzymes suggest existence of other, less homologous genes. Search of the GenBank database identified 45 L. esculentum ESTs with $97 \%$ to $100 \%$ sequence homology to the cloned P450 gene. Clustering of CYP72 genes has been observed in A. thaliana and Oryza sativa L. (rice) genomes (GenBank Accession No. AB023038; European Union Chromosome 3 Arabidopsis Genome Sequencing Consortium et al., 2000; GenBank Accession No. AP002839; Sasaki et al., 2000). A cluster of nine genes, one a pseudogene, was localized to chromosome 3 of A. thaliana (GenBank Accession No. AB023038; European Union Chromosome 3 Arabidopsis Genome Sequencing Consortium et al., 2000) and chromosome 1 of rice (GenBank Accession No. AP002839; Sasaki et al., 2000). Analysis of the N. plumbaginifolia genomic DNA suggested there are at least three copies of the $C Y P 72 A 2$ gene and of the two genes that have been cloned, one was found to be a pseudogene (Mujer and Smigocki, 2001). In the C. roseus CYP72 gene subfamily, three highly homologous genes were detected (Mangold et al., 1994). Studies to determine the function of the CYP72 genes may prove more fruitful in L. esculentum as the subfamily appears to have fewer genes than have been found in the other genomes.

The $C$. roseus $C Y P 72 A 1$ gene has recently been shown to code for secologanin synthase, an early-stage enzyme in the indole alkaloid biosynthetic pathway that converts loganin to secologanin (Irmler et al., 2000). Initial studies to determine enzyme activity suggested that $C Y P 72 A 1$ codes for geraniol-10-hydroxylase, an enzyme that catalyzes a rate limiting conversion of geraniol to $10-$ hydroxygeraniol, an earlier reaction in the pathway for secologanin synthesis (Mangold et al., 1994; Meijer et al., 1993; Vetter et al., 1992). Monoterpene alkaloids that are synthesized via the secologanin branch of the pathway include powerful anticancer drugs (camptothecin, vinblastine, and vincristine) and a compound with insecticidal activity (vincristine). Since the $L$. esculentum $\mathrm{P} 450$ clone shares $45 \%$ identity with the $C$. roseus secologanin synthase enzyme, it is presumed that it will hydroxylate a different substrate. Its function is speculated to be similar to the yet undetermined $N$. plumbaginifolia $C Y P 72 A 2$ gene function as the clones share $75 \%$ homology at the protein and nucleotide level.

Expression Patterns of THE P450 Gene. A tissue specific expression pattern of the P450 gene was observed in L. esculentum plants. Highest levels of a $1.5 \mathrm{~kb}$ transcript were detected in shoot meristems, young leaves, and fruit $1 \mathrm{~cm}$ in diameter (Fig. 2). Reduced levels of expression were noted in roots, stems, and mature leaves and no transcripts were detected in mature flowers and green fruit. The $45 \mathrm{~L}$. esculentum ESTs with high sequence homology to the L. esculentum CYP72 gene were cloned prima-

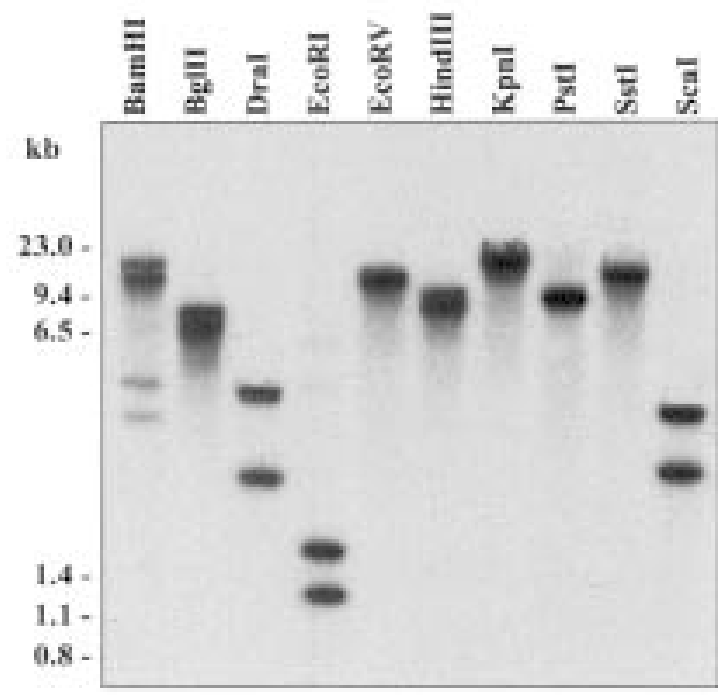

Fig. 1. Southern-blot analysis of the L. esculentum $\mathrm{P} 450$ gene. Genomic DNA was digested with restriction enzymes BamHI, BglII, DraI, EcoRI, EcoRV, HindIII, KpnI, PstI, SstI, or ScaI. A ${ }^{32} \mathrm{P}$-labeled $0.4 \mathrm{~kb}$ DNA fragment specific for the 5 'end of cloned L.esculentum $\mathrm{P} 450 \mathrm{cDNA}$ was used as a probe.
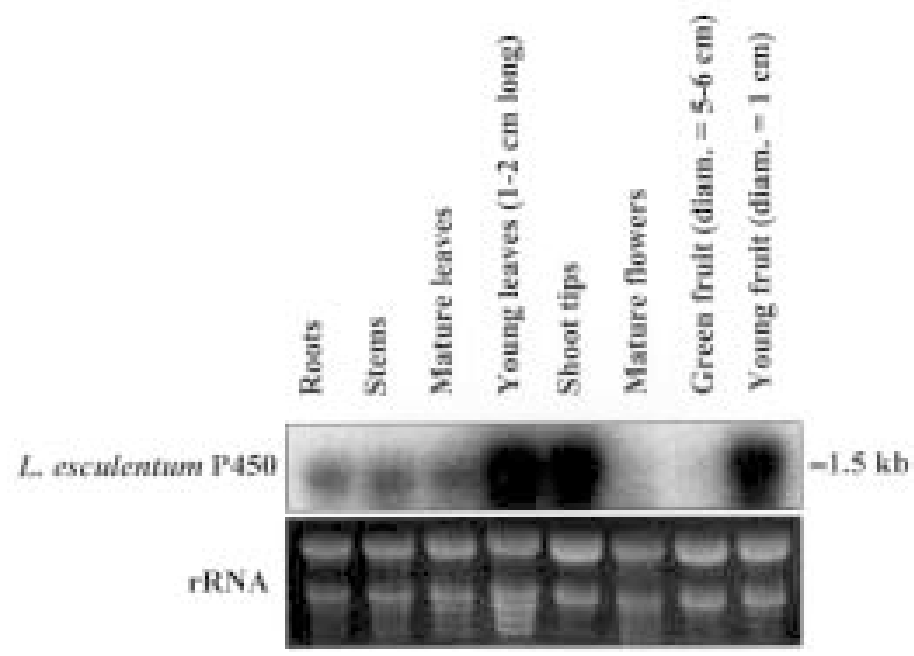

Fig. 2. Tissue specific expression pattern of the cloned L. esculentum cytochrome P450 cDNA. RNA from roots, stems, mature leaves, young leaves, shoot tips, mature flowers, green fruit, and young fruit was blotted and hybridized with a ${ }^{32} \mathrm{P}$-labeled $0.4 \mathrm{~kb}$ DNA fragment as in Fig. 1. Before blotting, gels were stained with ethidium bromide and the intensity of the stained rRNA was used as a control for equal loading of the RNA in each lane. 

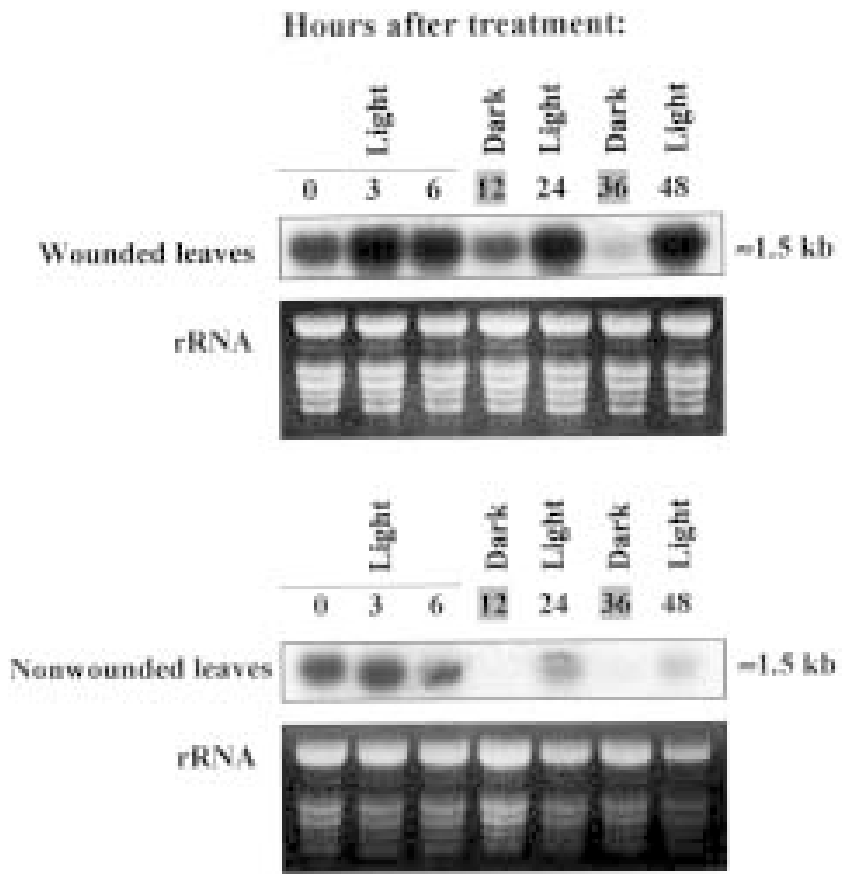

Fig. 3.Lycopersicon esculentum $\mathrm{P} 450 \mathrm{RNA}$ accumulation in response to mechanical wounding. RNA transcripts were analyzed by northern hybridization. Leaves from mechanically wounded and nonwounded plants were collected at $0(0900$ $\mathrm{HR}), 3(1200 \mathrm{HR}), 6$ (1500 HR), $12(2100 \mathrm{HR}) 24$ (0900 HR), 36 (2100 HR), and 48 $\mathrm{h}(0900 \mathrm{HR})$ after wounding and analyzed as in Fig. 2. rRNA was used as a control for equal loading of the RNA.

rily from flower buds but also included clones from shoot meristems, developing green fruit, and ovaries. It is interesting to note that many of the homologous ESTs were cloned from flower buds but our results did not show any expression in mature flowers (Fig. 2). Similar analysis of tissue specific expression of the $N$. plumbaginifolia and $C$. roseus cytochrome $\mathrm{P} 450$ genes has not been reported. By in situ hybridization, the $C$. roseus gene has been shown to be expressed mainly in the upper and lower epidermis of immature leaves (Irmler et al., 2000). In $N$. plumbaginifolia, the $C Y P 72 A 2$ gene was expressed in young and mature leaves (Mujer and Smigocki, 2001). Analysis of 11 Arabidopsis genes revealed that expression patterns were variable in roots, leaves, inflorescence stems, flowers, and siliques even when genes were members of the same subfamilies (Mizutani et al., 1998).

WOUND- AND CYTOKININ-INDUCED P450 GENE EXPRESSION. Transcript levels of the L. esculentum clone were analyzed in fully expanded leaves over a $48 \mathrm{~h}$ period (Fig. 3). In nonwounded leaves, expression levels were low during the day. At night, transcripts were undetected at $2100 \mathrm{HR}$ ( $12 \mathrm{~h}$ time point) and very low after $36 \mathrm{~h}$. These results suggest the influence of circadian rhythm and light on the L. esculentum P450 gene expression as was observed with the $N$. plumbaginifolia CYP72A2 gene (Mujer and Smigocki, 2001). Wounding increased transcript levels to maximum after $3 \mathrm{~h}$ (Fig. 3). Even though transcript levels in wounded and nonwounded plants were the lowest and almost the same after $36 \mathrm{~h}(2100 \mathrm{HR})$, they were higher in wounded plants after $48 \mathrm{~h}(0900 \mathrm{HR})$. The strong wound response is similar to the one reported for the CYP72A2 gene (Mujer and Smigocki, 2001). Other cytochrome P450 enzymes that are involved primarily in the phenylpropanoid biosynthetic pathway also have been shown to be induced by wounding stress and include $C Y P 73 A 9$ and CYP82 from Pisum sativum L. (pea) (Frank et al., 1996) and
CYP71B3, CYP71B6, CYP73A5, CYP83B1, and CYP91A1 from A. thaliana (Mizutani et al., 1998).

Since the N. plumbaginifolia CYP72A2 gene was shown to be induced by cytokinins, L. esculentum plants were either sprayed with zeatin or excised petioles were placed in zeatin solutions (Harding and Smigocki, 1994; Mujer and Smigocki, 2001). These treatments had minimal effects on expression of the P450 gene (data not presented) suggesting that the L. esculentum gene is not regulated by zeatin like the $N$. plumbaginifolia $C Y P 72 A 2$ gene. However, possible problems of uptake and metabolism of the exogenously supplied zeatin cannot be ruled out. To our knowledge, effects of cytokinins on expression levels of other cytochrome $\mathrm{P} 450$ genes have not been reported.

Lycopersicon esculentum TRANSFORMATION. More than 1400 cotyledons were infected with $A$. tumefaciens strains carrying the $C Y P 72 A 2$ gene constructs. Transgenic plants were not regenerated with plasmids pFLS, pFLAS, or pTRAS carrying the CaMV35S promoter fused to the full-length sense or antisense gene fragments except for the controls. Of the 184 explants inoculated with the $35 \mathrm{~S}-\mathrm{GUS}$ construct, 32 produced callus and 17 of them regenerated GUS positive shoots. Transformation of $N$. plumbaginifolia with the same plasmids did not produce transgenic plants except with the control (Smigocki and Wilson, unpublished). With the pPin2FLS plasmid, 16 calli were recovered from more than 200 infected L. esculentum cotyledons. However, all calli died within 8 weeks and no shoots regenerated during that period.

Our data suggest that overexpression of the $C Y P 72 A 2$ gene with the constitutive CaMV $35 \mathrm{~S}$ promoter produced a build up of toxic levels of a secondary metabolite(s), possibly an indole alkaloid, leading to cell death. In tissues transformed with the P450 gene fused to the wound-inducible Pin2 promoter (pPin2FLS), the build up of toxic compounds would be expected to be reduced or to accumulate at a slower rate allowing some initial callus growth. On the other hand, since no plants were regenerated with the antisense gene constructs, it is also possible that this enzyme could be involved in synthesis of a compound that plays a critical role in normal cell growth and development in L. esculentum and N. plumbaginifolia. The possible cosuppression of gene expression or feedback inhibition of the corresponding pathway with the constitutively expressed sense gene would also support an important role for this P450 gene in cell growth and development. Fusion of the gene to a stringently regulated promoter for controlled temporal or tissue specific expression should promote regeneration of transgenic plants that would be used to further characterize the structure and function of these P450 genes in vivo.

\section{Literature Cited}

Altschul, S.F., T.L. Madden, A.A. Schäffer, J. Zhang, Z. Zhang, W. Miller, and D.J. Lipman. 1997. Gapped BLAST and PSI-BLAST: A new generation of protein database search programs. Nucleic Acids Res. 25:3389-3402.

Bartoszewski, G., S. Malepszy, and K. Niemirowicz-Szczytt. 1996. Transformation in selected forms of the tomato Lycopersicon esculentum Mill. using Agrobacterium tumefaciens. J. Appl. Genet. 37A:97-100. Church, G.M. and W. Gilbert. 1984. Genomic sequencing. Proc. Natl. Acad. Sci. USA 81:1991-1995.

Dellaporta, S.L., J. Woods, and J.B. Hicks. 1984. Maize DNA miniprep, p. 36-37. In: R. Malmberg, J. Messing, and I. Sussex (eds.). Molecular biology of plants: A Laboratory course manual. Cold Spring Harbor Press, Cold Spring Harbor, N.Y.

European Union Chromosome 3 Arabidopsis Genome Sequencing Con- 
sortium, Institute For Genomic Research and Kazusa DNA Research Institute. 2000. Sequence and analysis of chromosome 3 of the plant Arabidopsis thaliana. Nature 408:820-823.

Frank, M.R., J.M. Deyneka, and M.A. Schuler. 1996. Cloning of woundinduced cytochrome P450 monooxygenases expressed in pea. Plant Physiol. 110:1035-1046.

Harding, S.A. and A.C. Smigocki. 1994. Cytokinins modulate stress response genes in isopentenyl transferase transformed Nicotiana plumbaginifolia plants. Physiol. Plant. 90:327-333.

Irmler, S., G. Schröder, B. St-Pierre, N.P. Crouch, M. Hotze, J. Schmidt, D. Strack, U. Matern, and J. Schröder. 2000. Indole alkaloid biosynthesis in Catharanthus roseus: New enzyme activities and identification of cytochrome P450 CYP72A1 as secologanin synthase. Plant J. 24:797-804.

Jefferson, R.A., T.A. Kavanagh, and M.W. Bevan. 1987. GUS fusions: Beta-glucuronidase as a sensitive and versatile gene fusion marker in higher plants. EMBO J. 6:3901-3907.

Mangold, U., J.Eichel, A. Batschauer, T.Lanz, T. Kaiser, G. Spangenberg, D. Werck-Reichhart, and J. Schröder. 1994. Gene and cDNA for plant cytochrome $\mathrm{P} 450$ proteins (CYP72 family) from Catharanthus roseus, and transgenic expression of the gene and a cDNA in tobacco and Arabidopsis thaliana. Plant Sci. 96:129-136.

McCormick, S., J. Niedermeyer, J. Fry, A. Barnason, R. Horsch, and R. Fraley. 1986. Leaf disc transformation of cultivated tomato $(L$. esculentum) using Agrobacterium tumefaciens. Plant Cell Rpt. 5:8184.

Meijer, A.H., R. Verpoote, and J.H.C. Hoge. 1993. Regulation of enzymes and genes involved in terpenoid indole alkaloid biosynthesis in Catharanthus roseus. J. Plant Res. 3:145-164.

Mizutani, M., E. Ward, and D. Ohta. 1998. Cytochrome P450 superfamily in Arabidopsis thaliana: Isolation of cDNAs, differential expression and RFLP mapping of multiple cytochromes P450. Plant Mol. Biol. 37:39-52.
Mujer, C.V. and A.C. Smigocki. 2001. Cytokinin- and wound-inducible cytochrome P450 from Nicotiana plumbaginifolia. Physiol. Plant. 111:172-181.

Murashige, T. and F. Skoog. 1962. A revised medium for rapid growth and bioassays with tobacco tissue cultures. Physiol. Plant. 15:473-497.

Nebert, D.W. and F.J. Gonzalez. 1987. P450 genes: Structure, evolution and regulation. Annu. Rev. Biochem. 56:945-993.

Nelson, D.R. 1999. Cytochrome P450 and the individuality of species. Arch. Biochem. Biophys. 369:1-10.

O'Keefe, D.P., J.M. Tepperman, C. Dean, K.J. Leto, D.L. Erbes, and J.T. Odell. 1994. Plant expression of a bacterial cytochrome P450 that catalyses activation of a sulfonylurea pro-herbicide. Plant Physiol. 105:473-482.

Sasaki, T., T. Matsumoto, and K. Yamamoto. 2000. Oryza sativa nipponbare(GA3) genomic DNA, chromosome 1, PAC clone: P0688A04. GenBank Accesion Number AP002839.

Schuler, M.A. 1996. Plant cytochrome P450 monooxygenases. Crictical Rev. Plant Sci. 15:235-284.

Shiota, N., A. Nagasawa, T. Sakaki, Y. Yabusaki, and H. Ohkaw. 1994. Herbicide-resistant tobacco plants expressing the fused enzyme between rat cytochrome P4501A1 (CYPIAI) and yeast NADPH-Cytochrome P450 oxidoreductase. Plant Physiol. 106:17-23.

Thompson, J.D., D.G. Higgins, and T.J. Gibson. 1994. CLUSTAL W: Improving the sensitivity of progressive multiple sequence alignment through sequence weighting, position-specific gap penalties and weight matrix choice. Nucleic Acids Res. 22:4673-4680.

Vetter, H.P., U. Mangold, G. Schröder, F.J. Marner, D. Werck-Reichhart, and J. Schröder. 1992. Molecular analysis and heterologous expression of an inducible cytochrome P-450 protein from periwinkle (Catharanthus roseus L.). Plant Physiol. 100:998-1007.

Werck-Reichhart, D., A. Hehn, and L. Didierjean. 2000. Cytochromes P450 for engineering herbicide tolerance. Trends in Plant Sci. 5:116123. 